\title{
Synthesis, spectral correlations and biological activities of some (E)-[4-(substituted benzylidene amino)phenyl] (phenyl) methanones
}

\author{
P. Mayavel, K. Thirumurthy, S. Dineshkumar, G. Thirunarayanan* \\ Department of Chemistry, Annamalai University, Annamalainagar 608 002, India \\ *E-mail address: drgtnarayanan@gmail.com
}

\begin{abstract}
A series of Schiff's bases have been synthesized by fly-ash:p-toluenesulfonic acid (fly-ash:PTS) catalyzed microwave assisted oxidative coupling of arylamines and substituted benzaldehydes under solvent-free condition. The synthesized Schiff's bases are characterized by their physical constants, analytical and spectroscopic data. The group frequencies of imines such as IR $\left(v, \mathrm{~cm}^{-1}\right)$ and NMR $(\delta$, ppm) spectral data was correlated with Hammett substituent constants, F and R parameters using single and multi-linear regression analysis. The antimicrobial activities of these Schiff's bases have been studied using Bauer-Kirby method.
\end{abstract}

Keywords: Schiff's bases; Fly-ash:PTS; IR spectra; NMR spectra; Hammett correlation

\section{INTRODUCTION}

The formation of carbon-nitrogen double bond plays important role in organic synthesis. This can be achieved by the reaction of aldehyde and amines in acidic medium which leads to synthesis of imines (or) Schiff's bases [1]. Imines are compound containing the functional group $(-\mathrm{CH}=\mathrm{N}-)$ and they are generally called azomethine. Many Schiff's bases are known to be medicinally important and are used to design medicinal compounds [2]. They are well known intermediated for the preparation of azetidinone [3], thiazolidinone [4], formazone [5], arylacetamide [6], metal complexes [7-9] and many other derivatives [10-11]. Many reagent have been used for the synthesis of optically active imines such as Lewis acids [12], $\mathrm{MnO}_{2}$ [13], $\mathrm{CaO}$ [14], $\mathrm{ZnCl}_{2}$ [15], $\mathrm{P}_{2} \mathrm{O}_{5}: \mathrm{SiO}_{2}$ [16], infrared [17], ultrasound radiation [18] and fly-ash: $\mathrm{H}_{2} \mathrm{SO}_{4}$ [19] with microwave irradiation. Schiff bases possess various biological activities such as anti-inflammatory [20], antibacterial [21], antifungal [22], antitubercular [23], anticancer [24], antimalarial [25] and anti-tumour [26], etc. Schiff bases are important intermediate for the synthesis of some bioactive compound such as $\beta$-lactams [2729].

The spectroscopic data are useful for prediction of ground state molecular equilibration such as s-cis and s-trans conformers of chalcones, cis and trans isomers of alkenes, alkynes, imines, $\omega$-bromo acyl esters [30-46]. The reactivity of spectral functional group frequencies were predicted with Hammett correlation. Suresh et al. [19] have studied the substituent effects of some 4-methoxyphenylimines by spectral correlations. Thirunarayanan and his coworkers [47-49] have investigated the spectral study and antimicrobial activities of some trifluoromethylimines. 
The effect of substituents on some symmetrical diimines has been studied by Thirunarayanan [50]. The spectral correlation and antimicrobial activity of some benzylidene pyridine-2-amine and benzylidene-3-nitrobenzenamine have been investigated by Sakthinathan et al. [51,52]. Recently, Mayavel et al. [43] have studied the solvent-free synthesis, spectral correlation and antimicrobial activities of some $(E)$-N-(substituted benzylidene)-9-ethyl-9H-carbazole-3-amines. Within the above view, there is no report available for synthesis, spectral correlations and antimicrobial activities of $(E)$-[4-(substituted benzylideneamino)-phenyl](phenyl)methanone in the past.

Therefore the authors have taken efforts to synthesis some (E)-[4-(substituted benzylideneamino) phenyl] (phenyl) methanones by fly-ash:PTS catalyzed condensation of 4aminobenzophenone with substituted benzaldehydes to study the substituent effect by correlation analysis using Hammett substituent constants. The biological activities of these imines derivatives have been studied using Bauer-Kirby [53] method.

\section{EXPERIMENTAL}

\section{1. Materials and methods}

All chemicals used in this work were purchased from Sigma-Aldrich Chemical Companies. Melting points of all imines have been determined in open glass capillaries on SUNTEX melting point apparatus and are uncorrected. Infrared spectra $\left(\mathrm{KBr}, 4000-400 \mathrm{~cm}^{-1}\right)$ have been recorded on Avatar-300 Fourier transform spectrophotometer (Thermo Nicolet, USA). The NMR spectra of all imines were recorded in Bruker AV 400 NMR spectrometer operating at $400 \mathrm{MHz}$ frequency for recording ${ }^{1} \mathrm{H}$ NMR spectra and $100 \mathrm{MHz}$ for ${ }^{13} \mathrm{C} \mathrm{NMR}$ spectra in $\mathrm{CDCl}_{3}$ solvent using TMS as internal standard.

\section{2. Synthesis of imines}

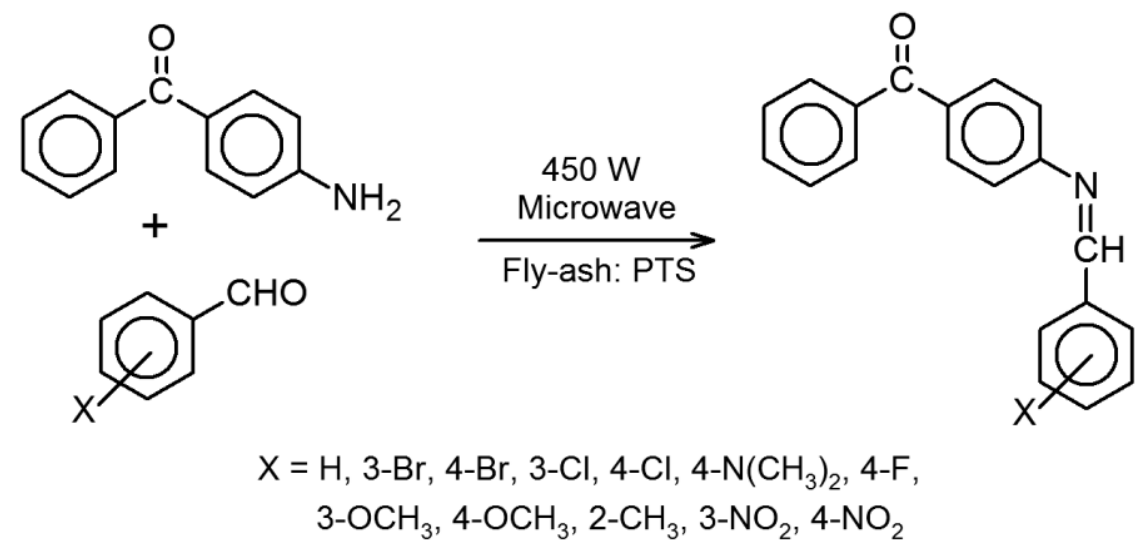

Scheme 1. Synthesis of (E)-[4-(substituted benzylideneamino)phenyl](phenyl)methanones.

An appropriate equimolar quantities of aryl amines $(2 \mathrm{mmol})$, substituted benzaldehyde $(2 \mathrm{mmol})$ and fly-ash:PTS $(0.5 \mathrm{~g})$ have been taken in borosil tube and tightly capped. This mixture was subjected to microwave irradiation for 6-8 minutes in a microwave oven at 450 W [Samsung, GW73BD model, $230 \mathrm{~V}, 50 \mathrm{~Hz}, 100 \mathrm{~N} / 750 \mathrm{~W}$ (ICE-705)] (Scheme 1). The progress of the reaction was monitored by TLC. After completion of the reaction, added 10 $\mathrm{mL}$ dichloromethane, the organic layer has been separated which on evaporation yields the 
solid product. The solid was purified by recrystallized using methanol. The analytical, physical constants and spectral data of all imines are presented in Table 1.

Table 1. Analytical, physical constants and spectral data of (E)-[4-(substituted benzylidene amino)phenyl](phenyl)methanones.

\begin{tabular}{|c|c|c|c|c|c|c|c|c|c|c|c|}
\hline \multirow{2}{*}{ Entry } & \multirow{2}{*}{$X$} & \multirow{2}{*}{ MF } & \multirow{2}{*}{ MW } & \multirow{2}{*}{$\begin{array}{l}\text { Yield } \\
(\%)\end{array}$} & \multirow{2}{*}{$\begin{array}{l}\text { m.p. } \\
\left({ }^{\circ} \mathrm{C}\right)\end{array}$} & \multicolumn{2}{|c|}{$\operatorname{IR}\left(\mathrm{cm}^{-1}\right)$} & \multirow{2}{*}{$\begin{array}{c}\begin{array}{c}{ }^{1} \mathrm{H} \text { NMR } \\
(\delta, \mathrm{ppm})\end{array} \\
\delta_{\mathrm{CH}}\end{array}$} & \multicolumn{2}{|c|}{$\begin{array}{l}{ }^{13} \mathrm{C} \text { NMR } \\
(\delta, \mathrm{ppm}) \\
\end{array}$} & \multirow{2}{*}{$\operatorname{Mass}(\mathrm{m} / \mathrm{z})$} \\
\hline & & & & & & $v_{\mathrm{C}=\mathrm{N}}$ & $v_{\mathrm{C}=\mathrm{O}}$ & & $\delta_{\mathrm{C}=\mathrm{N}}$ & $\delta_{\mathrm{C}=\mathrm{O}}$ & \\
\hline 1 & $\mathrm{H}$ & $\mathrm{C}_{20} \mathrm{H}_{15} \mathrm{NO}$ & 285 & 80 & 109-111 & 1589.46 & 1623.63 & 8.466 & 161.95 & 195.51 & $\begin{array}{l}285\left(\mathrm{M}^{+}\right) \\
286\left(\mathrm{M}^{1+}\right)\end{array}$ \\
\hline 2 & $3-\mathrm{Br}$ & $\mathrm{C}_{20} \mathrm{H}_{14} \mathrm{BrNO}$ & 363 & 84 & $158-160$ & 1591.92 & 1641.36 & 8.108 & 166.63 & 194.79 & $363\left(\mathrm{M}^{+}\right)$ \\
\hline 3 & $4-\mathrm{Br}$ & $\mathrm{C}_{20} \mathrm{H}_{14} \mathrm{BrNO}$ & 363 & 82 & $130-132$ & 1592.12 & 1620.64 & 8.419 & 160.39 & 195.30 & $363\left(\mathrm{M}^{+}\right)$ \\
\hline 4 & $3-\mathrm{Cl}$ & $\mathrm{C}_{20} \mathrm{H}_{14} \mathrm{ClNO}$ & 319 & 78 & $106-108$ & 1577.77 & 1635.64 & 8.435 & 160.10 & 195.99 & $\begin{array}{c}319\left(\mathrm{M}^{+}\right) \\
320\left(\mathrm{M}^{1+}\right)\end{array}$ \\
\hline 5 & $4-\mathrm{Cl}$ & $\mathrm{C}_{20} \mathrm{H}_{14} \mathrm{ClNO}$ & 319 & 80 & $88-90$ & 1581.63 & 1631.78 & 8.436 & 160.35 & 190.99 & $\begin{array}{c}319\left(\mathrm{M}^{+}\right) \\
320\left(\mathrm{M}^{1+}\right) \\
\end{array}$ \\
\hline 6 & $4-\mathrm{N}\left(\mathrm{CH}_{3}\right)_{2}$ & $\mathrm{C}_{22} \mathrm{H}_{20} \mathrm{~N}_{2} \mathrm{O}$ & 328 & 85 & $138-140$ & 1573.91 & 1637.78 & 8.335 & 161.42 & 195.36 & $328\left(\mathrm{M}^{+}\right)$ \\
\hline 7 & $4-\mathrm{F}$ & $\mathrm{C}_{20} \mathrm{H}_{14} \mathrm{FNO}$ & 303 & 79 & $82-84$ & 1575.84 & 1627.92 & 8.423 & 160.30 & 195.43 & $303\left(\mathrm{M}^{+}\right)$ \\
\hline 8 & $3-\mathrm{OCH}_{3}$ & $\mathrm{C}_{21} \mathrm{H}_{17} \mathrm{NO}_{2}$ & 315 & 81 & $90-92$ & 1586.60 & 1621.98 & 8.467 & 160.01 & 192.30 & $316\left(\mathrm{M}^{1+}\right)$ \\
\hline 9 & $4-\mathrm{OCH}_{3}$ & $\mathrm{C}_{21} \mathrm{H}_{17} \mathrm{NO}_{2}$ & 315 & 82 & $96-98$ & 1583.56 & 1635.64 & 8.399 & 161.04 & 195.37 & $316\left(\mathrm{M}^{1+}\right)$ \\
\hline 10 & $2-\mathrm{CH}_{3}$ & $\mathrm{C}_{21} \mathrm{H}_{17} \mathrm{NO}$ & 299 & 80 & 104-106 & 1587.42 & 1633.71 & 8.755 & 160.55 & 195.48 & $299\left(\mathrm{M}^{+}\right)$ \\
\hline 11 & $3-\mathrm{NO}_{2}$ & $\mathrm{C}_{20} \mathrm{H}_{14} \mathrm{~N}_{2} \mathrm{O}_{3}$ & 330 & 78 & $108-110$ & 1585.49 & 1639.49 & 8.572 & 158.82 & 195.88 & $330\left(\mathrm{M}^{+}\right)$ \\
\hline 12 & $4-\mathrm{NO}_{2}$ & $\mathrm{C}_{20} \mathrm{H}_{14} \mathrm{~N}_{2} \mathrm{O}_{3}$ & 330 & 80 & $140-142$ & 1589.34 & 1637.56 & 8.583 & 159.01 & 190.31 & $330\left(\mathrm{M}^{+}\right)$ \\
\hline
\end{tabular}

\section{RESULTS AND DISCUSSION}

\section{1. Spectral linearity}

In the present study the spectral linearity of synthesized imines has been studied by

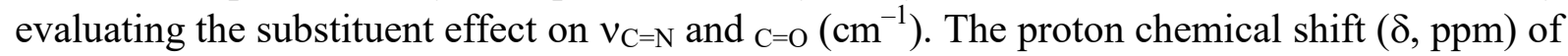
$\mathrm{CH}=\mathrm{N}$ and carbon chemical shift of $\mathrm{C}=\mathrm{N}$ and $\mathrm{C}=\mathrm{O}$ have been correlated with Hammett substituent constants $\mathrm{F}$ and $\mathrm{R}$ parameters using single and multi-linear regression analysis.

\section{1. 1. IR spectral study}

The recorded infrared $v_{\mathrm{C}=\mathrm{N}}, v_{\mathrm{C}=\mathrm{O}}$ stretching frequencies $\left(\mathrm{cm}^{-1}\right)$ of the synthesized imines have been presented in Table 1. These data are correlated [19,30-52] with Hammett substituent constant F and R and Swain-Lupton's [54] parameters.

In this regression analysis the structure parameter correlation Hammett equation have been employed as shown in eqn. (1).

$$
v=\rho \sigma+v_{0}
$$

where $v_{0}$ is the frequency for the parent member series.

The assigned $v_{\mathrm{C}=\mathrm{N}}$ and $v_{\mathrm{C}=\mathrm{O}}$ stretching frequency $\left(\mathrm{cm}^{-1}\right)$ of the imine derivatives were correlated with various Hammett substituent constants $\mathrm{F}$ and $\mathrm{R}$ parameters are presented in Table 2. The correlation of $v_{\mathrm{C}=\mathrm{N}}\left(\mathrm{cm}^{-1}\right)$ frequency of imines with Hammett substituent 
constant $\mathrm{F}$ and $\mathrm{R}$ parameter is found to be fail with positive $\rho$ values except $\mathrm{F}$. The resonance conjugated the structure of the imine is shown in Fig. 1.

Table 2. Results of statistical analysis of IR $\left(v, \mathrm{~cm}^{-1}\right)$ of $\mathrm{C}=\mathrm{N}, \mathrm{C}=\mathrm{O}, \mathrm{NMR}(\delta$, ppm $)$ of $\mathrm{CH}, \mathrm{C}=\mathrm{N}$ and $\mathrm{C}=\mathrm{O}$ of $(E)$-[4-(substituted benzylideneamino)phenyl](phenyl)methanones with Hammett substituent constants, $\mathrm{F}$ and $\mathrm{R}$ parameters.

\begin{tabular}{|c|c|c|c|c|c|c|c|}
\hline Frequency & Const. & $\mathbf{r}$ & I & $\rho$ & $\mathbf{s}$ & $\mathbf{n}$ & Correlated derivatives \\
\hline \multirow{6}{*}{$v_{\mathrm{C}=\mathrm{N}}$} & $\sigma$ & 0.753 & 1583.59 & 6.741 & 5.75 & \multirow{6}{*}{12} & \multirow{6}{*}{$\begin{array}{c}\mathrm{H}, 3-\mathrm{Br}, 4-\mathrm{Br}, 3-\mathrm{Cl}, 4-\mathrm{Cl}, 4-\mathrm{N}\left(\mathrm{CH}_{3}\right)_{2}, \\
\text { 4-F, 3- }-\mathrm{OCH}_{3}, 4-\mathrm{OCH}_{3}, 2-\mathrm{CH}_{3}, \\
\text { 3- } \mathrm{NO}_{2}, 4-\mathrm{NO}_{2}\end{array}$} \\
\hline & $\sigma^{+}$ & 0.872 & 1584.37 & 5.013 & 5.29 & & \\
\hline & $\sigma_{\mathrm{I}}$ & 0.759 & 1584.04 & 1.525 & 6.44 & & \\
\hline & $\sigma_{\mathrm{R}}$ & 0.811 & 1587.82 & 16.24 & 5.10 & & \\
\hline & $\mathrm{F}$ & 0.792 & 1585.47 & -2.35 & 6.42 & & \\
\hline & $\mathrm{R}$ & 0.826 & 1587.93 & 11.67 & 5.03 & & \\
\hline \multirow{6}{*}{$v_{C}=0$} & $\sigma$ & 0.860 & 1631.84 & 2.744 & 7.322 & \multirow{6}{*}{12} & \multirow{6}{*}{$\begin{array}{c}\mathrm{H}, 3-\mathrm{Br}, 4-\mathrm{Br}, 3-\mathrm{Cl}, 4-\mathrm{Cl}, 4-\mathrm{N}\left(\mathrm{CH}_{3}\right)_{2}, \\
\text { 4-F, 3- } \mathrm{OCH}_{3}, 4-\mathrm{OCH}_{3}, 2-\mathrm{CH}_{3}, \\
\text { 3- } \mathrm{NO}_{2}, 4-\mathrm{NO}_{2}\end{array}$} \\
\hline & $\sigma^{+}$ & 0.824 & 1632.39 & -1.251 & 7.361 & & \\
\hline & $\sigma_{\mathrm{I}}$ & 0.862 & 1629.48 & 7.791 & 7.158 & & \\
\hline & $\sigma_{\mathrm{R}}$ & 0.795 & 1633.43 & 5.978 & 7.275 & & \\
\hline & $\mathrm{F}$ & 0.708 & 1627.94 & 6.113 & 7.256 & & \\
\hline & $\mathrm{R}$ & 0.720 & 1632.86 & 2.160 & 7.381 & & \\
\hline \multirow{6}{*}{$\delta_{\mathrm{CH}}$} & $\sigma$ & 0.901 & 8.443 & 0.046 & 0.160 & \multirow{2}{*}{10} & \multirow{2}{*}{$\begin{array}{c}\mathrm{H}, 4-\mathrm{Br}, 3-\mathrm{Cl}, 4-\mathrm{Cl}, 4-\mathrm{N}\left(\mathrm{CH}_{3}\right)_{2}, 4-\mathrm{F} \\
\text { 3- } \mathrm{OCH}_{3}, 4-\mathrm{OCH}_{3}, 3-\mathrm{NO}_{2}, 4-\mathrm{NO}_{2}\end{array}$} \\
\hline & $\sigma^{+}$ & 0.901 & 8.448 & 0.037 & 0.159 & & \\
\hline & $\sigma_{\mathrm{I}}$ & 0.839 & 8.481 & -0.090 & 0.159 & 12 & $\begin{array}{c}\mathrm{H}, 3-\mathrm{Br}, 4-\mathrm{Br}, 3-\mathrm{Cl}, 4-\mathrm{Cl}, 4-\mathrm{N}\left(\mathrm{CH}_{3}\right)_{2}, \\
\text { 4-F, 3- } \mathrm{OCH}_{3}, 4-\mathrm{OCH}_{3}, 2-\mathrm{CH}_{3}, \\
\text { 3- } \mathrm{NO}_{2}, 4-\mathrm{NO}_{2}\end{array}$ \\
\hline & $\sigma_{\mathrm{R}}$ & 0.903 & 8.497 & 0.238 & 0.150 & \multirow{3}{*}{10} & \multirow{3}{*}{$\begin{array}{c}\mathrm{H}, 4-\mathrm{Br}, 3-\mathrm{Cl}, 4-\mathrm{Cl}, 4-\mathrm{N}\left(\mathrm{CH}_{3}\right)_{2}, \\
\text { 4-F, 3-OCH } 3 \text {, 4-OCH } \\
\text { 3- } \mathrm{NO}_{2}, 4-\mathrm{NO}_{2}\end{array}$} \\
\hline & $\mathrm{F}$ & 0.901 & 8.483 & -0.090 & 0.159 & & \\
\hline & $\mathrm{R}$ & 0.903 & 8.500 & 0.178 & 0.149 & & \\
\hline \multirow{5}{*}{$\delta_{\mathrm{C}=\mathrm{N}}$} & $\sigma$ & 0.902 & 161.01 & -0.928 & 2.072 & 11 & $\begin{array}{c}\mathrm{H}, 4-\mathrm{Br}, 3-\mathrm{Cl}, 4-\mathrm{Cl}, 4-\mathrm{N}\left(\mathrm{CH}_{3}\right)_{2}, 4-\mathrm{F} \\
\text { 3-OCH }, 4-\mathrm{OCH}_{3}, 2-\mathrm{CH}_{3}, \\
\text { 3- } \mathrm{NO}_{2}, 4-\mathrm{NO}_{2} \\
\end{array}$ \\
\hline & $\sigma^{+}$ & 0.901 & 160.90 & -0.470 & 2.083 & 10 & $\begin{array}{c}\text { 4- } \mathrm{Br}, 3-\mathrm{Cl}, 4-\mathrm{Cl}, 4-\mathrm{N}\left(\mathrm{CH}_{3}\right)_{2}, 4-\mathrm{F} \\
\text { 3-- } \mathrm{OCH}_{3}, 4-\mathrm{OCH}_{3}, 2-\mathrm{CH}_{3} \\
\text { 3- }-\mathrm{NO}_{2}, 4-\mathrm{NO}_{2} \\
\end{array}$ \\
\hline & $\sigma_{\mathrm{I}}$ & 0.902 & 161.57 & -1.793 & 2.063 & 11 & $\begin{array}{c}\mathrm{H}, 4-\mathrm{Br}, 3-\mathrm{Cl}, 4-\mathrm{Cl}, 4-\mathrm{N}\left(\mathrm{CH}_{3}\right)_{2}, 4-\mathrm{F}, \\
\text { 3- } \mathrm{OCH}_{3}, 4-\mathrm{OCH}_{3}, 2-\mathrm{CH}_{3}, \\
\text { 3- } \mathrm{NO}_{2}, 4-\mathrm{NO}_{2}\end{array}$ \\
\hline & $\sigma_{\mathrm{R}}$ & 0.900 & 160.60 & -1.369 & 2.085 & 10 & $\begin{array}{c}\text { 4-Br, 3-Cl, 4-Cl, 4-N }\left(\mathrm{CH}_{3}\right)_{2}, 4-\mathrm{F}, \\
\text { 3-OCH } 3 \text {, 4-OCH }, 2-\mathrm{CH}_{3}, \\
\text { 3- } \mathrm{NO}_{2}, 4-\mathrm{NO}_{2} \\
\end{array}$ \\
\hline & $\mathrm{F}$ & 0.903 & 161.64 & -2.033 & 2.048 & 11 & $\begin{array}{c}\mathrm{H}, 4-\mathrm{Br}, 3-\mathrm{Cl}, 4-\mathrm{Cl}, 4-\mathrm{N}\left(\mathrm{CH}_{3}\right)_{2}, 4-\mathrm{F}, \\
\text { 3- }-\mathrm{OCH}_{3}, 4-\mathrm{OCH}_{3}, 2-\mathrm{CH}_{3},\end{array}$ \\
\hline
\end{tabular}




\begin{tabular}{|c|c|c|c|c|c|c|c|}
\hline & & & & & & & $3-\mathrm{NO}_{2}, 4-\mathrm{NO}_{2}$ \\
\hline & $\mathrm{R}$ & 0.904 & 160.60 & -0.953 & 2.085 & 10 & $\begin{array}{c}\text { 4- } \mathrm{Br}, 3-\mathrm{Cl}, 4-\mathrm{Cl}, 4-\mathrm{N}\left(\mathrm{CH}_{3}\right)_{2}, 4-\mathrm{F}, \\
\text { 3- } \mathrm{OCH}_{3}, 4-\mathrm{OCH}_{3}, 2-\mathrm{CH}_{3} \\
\text { 3- } \mathrm{NO}_{2}, 4-\mathrm{NO}_{2}\end{array}$ \\
\hline \multirow{6}{*}{$\delta_{\mathrm{C}=\mathrm{N}}$} & $\sigma$ & 0.857 & 194.64 & -1.720 & 1.950 & \multirow{6}{*}{12} & \multirow{6}{*}{$\begin{array}{c}\mathrm{H}, 3-\mathrm{Br}, 4-\mathrm{Br}, 3-\mathrm{Cl}, 4-\mathrm{Cl}, 4-\mathrm{N}\left(\mathrm{CH}_{3}\right)_{2} \\
\text { 4-F, 3-OCH }, 4-\mathrm{OCH}_{3}, 2-\mathrm{CH}_{3}, \\
\text { 3- } \mathrm{NO}_{2}, 4-\mathrm{NO}_{2}\end{array}$} \\
\hline & $\sigma^{+}$ & 0.829 & 194.43 & -0.937 & 1.975 & & \\
\hline & $\sigma_{\mathrm{I}}$ & 0.789 & 195.24 & -2.418 & 2.002 & & \\
\hline & $\sigma_{\mathrm{R}}$ & 0.795 & 194.05 & -1.687 & 2.051 & & \\
\hline & $\mathrm{F}$ & 0.823 & 195.13 & -1.968 & 2.032 & & \\
\hline & $\mathrm{R}$ & 0.796 & 194.05 & -1.189 & 2.051 & & \\
\hline
\end{tabular}

$\mathrm{r}=$ correlation coefficient, $\mathrm{I}=$ intercept, $\rho=$ slope, $\mathrm{s}=$ standard deviation, $\mathrm{n}=$ number of correlated derivatives.

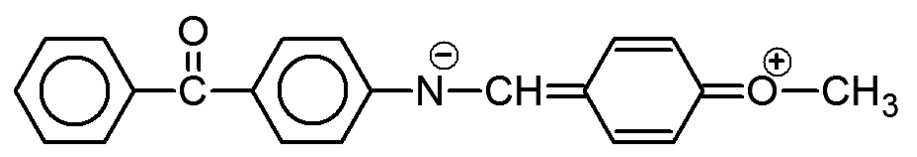

Fig. 1. The resonance-conjugative structure of imine.

The assigned the $v_{\mathrm{C}=\mathrm{O}}$ stretches were correlated with various Hammett substituent constants $\mathrm{F}$ and $\mathrm{R}$ parameter are presented in Table 2. The correlation of $v_{\mathrm{C}=\mathrm{O}}\left(\mathrm{cm}^{-1}\right)$ frequency of imines with Hammett substituent constant $\mathrm{F}$ and $\mathrm{R}$ parameters is found to be fail with positive $\rho$ values except $\sigma^{+}$. Single parameter correlation of $v_{C=N}$ and $v_{C=O}$ frequencies of imines failed with Hammett substituent constants while seeking the multi-linear correlation, these frequencies correlated satisfactory with inductive, resonance and Swain-Lupton constants [54] and correlated equations are given in (2-5).

$$
\begin{aligned}
v_{\mathrm{C}=\mathrm{N}}\left(\mathrm{cm}^{-1}\right)= & 1590.14( \pm 3.704)-5.347( \pm 0.756) \sigma_{\mathrm{I}}+18.365( \pm 7.370) \sigma_{\mathrm{R}} \\
& (\mathrm{R}=0.906, \mathrm{n}=12, \mathrm{P}>95) \\
v_{\mathrm{C}=\mathrm{N}}\left(\mathrm{cm}^{-1}\right)= & 1590.51( \pm 3.375)-6.109( \pm 0.687) \mathrm{F}+12.646( \pm 4.739) \mathrm{R} \\
& (\mathrm{R}=0.906, \mathrm{n}=12, \mathrm{P}>95) \\
v_{\mathrm{C}=\mathrm{O}}\left(\mathrm{cm}^{-1}\right)= & 1626.34( \pm 4.420)-5.021( \pm 3.881) \sigma_{\mathrm{I}}+17.280( \pm 9.424) \sigma_{\mathrm{R}} \\
& (\mathrm{R}=0.904, \mathrm{n}=12, \mathrm{P}>95) \\
v_{\mathrm{C}=\mathrm{O}}\left(\mathrm{cm}^{-1}\right)= & 1630.44( \pm 5.092)+5.742( \pm 0.987) \mathrm{F}+1.250( \pm 0.150) \mathrm{R} \\
& (\mathrm{R}=0.902, \mathrm{n}=12, \mathrm{P}>95)
\end{aligned}
$$

\section{1. 2. ${ }^{1} \mathrm{H}$ NMR spectral study}

The ${ }^{1} \mathrm{H}$ NMR spectral of the imines derivatives under the investigation have been recorded in deuterochloroform solution employing tetramethylsilane (TMS) as internal standard. The signals of the imine protons have been assigned and are presented in Table 1. In nuclear magnetic resonance spectra, the ${ }^{1} \mathrm{H}$ or the ${ }^{13} \mathrm{C}$ chemical shift $(\delta$, ppm) depend on the electronic environment of the nuclei concerned. The chemical shifts have been correlated with reactivity parameters. Thus the Hammett equation has been used in the form as shown in eqn. (6). 


$$
\delta=\delta_{0}+\rho \sigma
$$

where $\delta_{0}$ is the chemical shift of the corresponding parent compound.

The assigned proton chemical shift ( $\mathrm{ppm}$ ) of imines have been correlated with various Hammett constants, $\mathrm{F}$ and $\mathrm{R}$ parameters. The result of statistical analysis are presented in Table 2. The proton chemical shift ( $\delta \mathrm{ppm})$ with Hammett $\sigma, \sigma^{+}, \sigma_{\mathrm{R}}, \mathrm{F}$ and R constants is satisfactorily. The remaining Hammett constant $\sigma_{I}$ were found to be fail with positive $\rho$ values except $\sigma_{\mathrm{I}}$ and $\mathrm{F}$ excluding 3-Br, 2- $\mathrm{CH}_{3}$. This shows that the normal substituent effect operates in all system. The failure in correlation is attributed to the conjugated structure shown in Fig. 1. The authors think that, it is worthwhile to seek multiple correlations involving either $\sigma_{\mathrm{I}}$ and $\sigma_{\mathrm{R}}$ constant (or) Swain-Luptons $\mathrm{F}$ and $\mathrm{R}$ parameters. The correlation equation for $\mathrm{CH}$ proton chemical shift $(\delta, \mathrm{ppm})$ are given in eqns. (7 and 8$)$.

$$
\begin{aligned}
\delta \mathrm{CH}(\mathrm{ppm})= & 8.588( \pm 0.106)-0.211( \pm 0.116) \sigma_{\mathrm{I}}+0.322( \pm 0.112) \sigma_{\mathrm{R}} \\
& (\mathrm{R}=0.946, \mathrm{n}=12, \mathrm{P}>95) \\
\delta \mathrm{CH}(\mathrm{ppm})= & 8.564( \pm 0.101)-0.150( \pm 0.015) \mathrm{F}+0.201( \pm 0.012) \mathrm{R} \\
& (\mathrm{R}=0.944, \mathrm{n}=12, \mathrm{P}>95)
\end{aligned}
$$

\section{1. 3. ${ }^{13} \mathrm{C}$ NMR spectra}

Physical organic chemist and researches have been made extensive study of ${ }^{13} \mathrm{C}$ NMR spectra for a large number of ketones, styrenes, styryl ketones and keto-epoxides. They have studied linear correlations of the chemical shifts $(\mathrm{ppm})$ of $\mathrm{C}_{\alpha}, \mathrm{C}_{\beta}$ and $\mathrm{C}=\mathrm{O}$ carbons with Hammett $\sigma$ constants in alkenes, alkynes, acid chlorides and styrenes. In the present study, the chemical shifts (ppm) of imine $\mathrm{C}=\mathrm{N}$ and $\mathrm{C}=\mathrm{O}$ carbons have been assigned and are presented in Table 1. Attempts have been made to correlate these chemical shift $(\delta, \mathrm{ppm})$ with Hammett substituent constants, field and resonance parameters, with the help of single and multipleregression analysis to study the reactivity through the effect of substituent.

The chemical shift $(\delta, \mathrm{ppm})$ observed for the $\delta_{\mathrm{C}=\mathrm{N}}$ have been correlated with Hammett constants and the results of statistical analysis are presented in Table 2.

The $\delta_{\mathrm{C}=\mathrm{N}}$ chemical shift $(\delta$, ppm) gave satisfactory correlation with Hammett $\sigma$ constant $\mathrm{F}$ and $\mathrm{R}$ parameters along with negative $\rho$ values excluding $\left(\sigma, \sigma_{\mathrm{I}}, \mathrm{F}, 3-\mathrm{Br}, \sigma^{+}, \sigma_{\mathrm{R}}, \mathrm{R}, \mathrm{H}, 3-\mathrm{Br}\right)$ substituent. The chemical shift observed by $\delta_{\mathrm{C}=\mathrm{O}}$ carbon gave poor correlation with Hammett $\sigma$ constants $\mathrm{F}$ and $\mathrm{R}$ parameters with negative $\rho$ values.

This is due to the reason stated earlier and it is associated with the resonance conjugated structure as shown in Fig. 1. The author, think that it is worthwhile to seek multiple correlation involving all $\sigma_{\mathrm{I}}, \sigma_{\mathrm{R}}, \mathrm{F}$ and $\mathrm{R}$ parameters. This is given in the following correlation eqns. (9-12).

$$
\begin{aligned}
\delta \mathrm{C}=\mathrm{N}(\mathrm{ppm})= & 161.26( \pm 1.536)-1.504( \pm 0.969) \sigma_{\mathrm{I}}-0.772( \pm 0.057) \sigma_{\mathrm{R}} \\
& (\mathrm{R}=0.990, \mathrm{n}=12, \mathrm{P}>95) \\
\delta \mathrm{C}=\mathrm{N}(\mathrm{ppm})= & 161.38( \pm 1.431)-1.837( \pm 0.750) \mathrm{F}-0.662( \pm 0.019) \mathrm{R} \\
& (\mathrm{R}=0.992, \mathrm{n}=12, \mathrm{P}>95) \\
\delta \mathrm{C}=\mathrm{O}(\mathrm{ppm})= & 194.96( \pm 1.48)-2.09( \pm 0.87) \sigma_{\mathrm{I}}-0.85( \pm 0.012) \sigma_{\mathrm{R}} \\
& (\mathrm{R}=0.930, \mathrm{n}=12, \mathrm{P}>95) \\
\delta \mathrm{C}=\mathrm{O}(\mathrm{ppm})= & 194.76( \pm 1.41)-1.69( \pm 0.71) \mathrm{F}-0.92( \pm 0.013) \mathrm{R} \\
& (\mathrm{R}=0.928, \mathrm{n}=12, \mathrm{P}>95)
\end{aligned}
$$




\section{2. Antimicrobial activities}

\section{2. 1. Antibacterial sensitivity assay}

Table 3. Antibacterial activity of (E)-[4-(substituted benzylideneamino)phenyl](phenyl)methanones.

\begin{tabular}{|c|c|c|c|c|c|c|}
\hline \multirow{3}{*}{ Entry } & \multirow{3}{*}{$\mathbf{X}$} & \multicolumn{5}{|c|}{ Zone of inhibition (mm) } \\
\hline & & \multicolumn{3}{|c|}{ Gram-positive } & \multicolumn{2}{|c|}{ Gram-negative } \\
\hline & & B. subtilis & M. luteus & S. aureus & E. coli & P. aeruginosa \\
\hline 1 & $\mathrm{H}$ & - & - & - & - & 2 \\
\hline 2 & $3-\mathrm{Br}$ & - & - & - & 2 & - \\
\hline 3 & $4-\mathrm{Br}$ & - & - & - & - & 3 \\
\hline 4 & $3-\mathrm{Cl}$ & - & - & 1 & - & 2 \\
\hline 5 & $4-\mathrm{Cl}$ & 1 & 1 & - & - & 1 \\
\hline 6 & $4-\mathrm{N}\left(\mathrm{CH}_{3}\right)_{2}$ & - & - & 1 & - & - \\
\hline 7 & $4-\mathrm{F}$ & 1 & - & 1 & 2 & - \\
\hline 8 & $3-\mathrm{OCH}_{3}$ & - & - & 1 & - & - \\
\hline 9 & $4-\mathrm{OCH}_{3}$ & - & - & - & 2 & - \\
\hline 10 & $2-\mathrm{CH}_{3}$ & - & - & 2 & - & - \\
\hline 11 & $3-\mathrm{NO}_{2}$ & - & - & - & 1 & - \\
\hline 12 & $4-\mathrm{NO}_{2}$ & - & - & - & - & 1 \\
\hline \multicolumn{2}{|c|}{ Amacilin } & 8 & 3 & 6 & 4 & 1 \\
\hline \multicolumn{2}{|c|}{ DMSO } & - & - & - & - & - \\
\hline
\end{tabular}

Antibacterial sensitivity assay has been performed by using disc diffusion [53] technique. In each petri plate about $0.5 \mathrm{~mL}$ of the test bacterial sample has been spread uniformly over the solidified Mueller Hinton agar using sterile glass spreader. Then the disc with $5 \mathrm{~mm}$ diameter made up of Whatman No. 1 filter paper, impregnated with the solution of the compound have been placed on the medium using sterile forceps. The plates have been incubated for $24 \mathrm{~h}$ at $37{ }^{\circ} \mathrm{C}$ by keeping the plates upside down to prevent the collection of water droplets over the medium. After $24 \mathrm{~h}$, the plates have been visually examined and the diameter values of the zone of inhibition were measured. Triplicate results have been recorded by repeating the some procedure.

The antibacterial screening effect of synthesized Schiff's bases is shown in Fig. 3. The antibacterial activities of all the synthesized imines have been studied against three Grampositive pathogenic strains Bacillus subtilis, Micrococcus luteus, Staphylococcus aureus and two Gram-negative strains Pseudomonas aeruginosa, Escherichia coli. The disc diffusion technique was followed at a concentration of $250 \mu \mathrm{g} \mathrm{mL}^{-1}$ with Amacilin used as the standard drug. The zone of inhibition is compared using Table 3 and the corresponding clustered column chart is shown in Fig. 2. A good antibacterial activity has been possessed by all substituents in the microorganism in general. A satisfactory antibacterial activity against $B$. subtilis, M. luteus, S. aureus bacterial species when compared with standard Amacilin drugs. The substituents $3-\mathrm{Br}, 4-\mathrm{F}$ and $4-\mathrm{OCH}_{3}$ have moderate activity against $E$. coli. The 
substituents $\mathrm{H}, 4-\mathrm{Br}, 3-\mathrm{Cl}$ have excellent, $4-\mathrm{Cl}$ and $4-\mathrm{NO}_{2}$ have very good activity against $P$. aeruginosa.

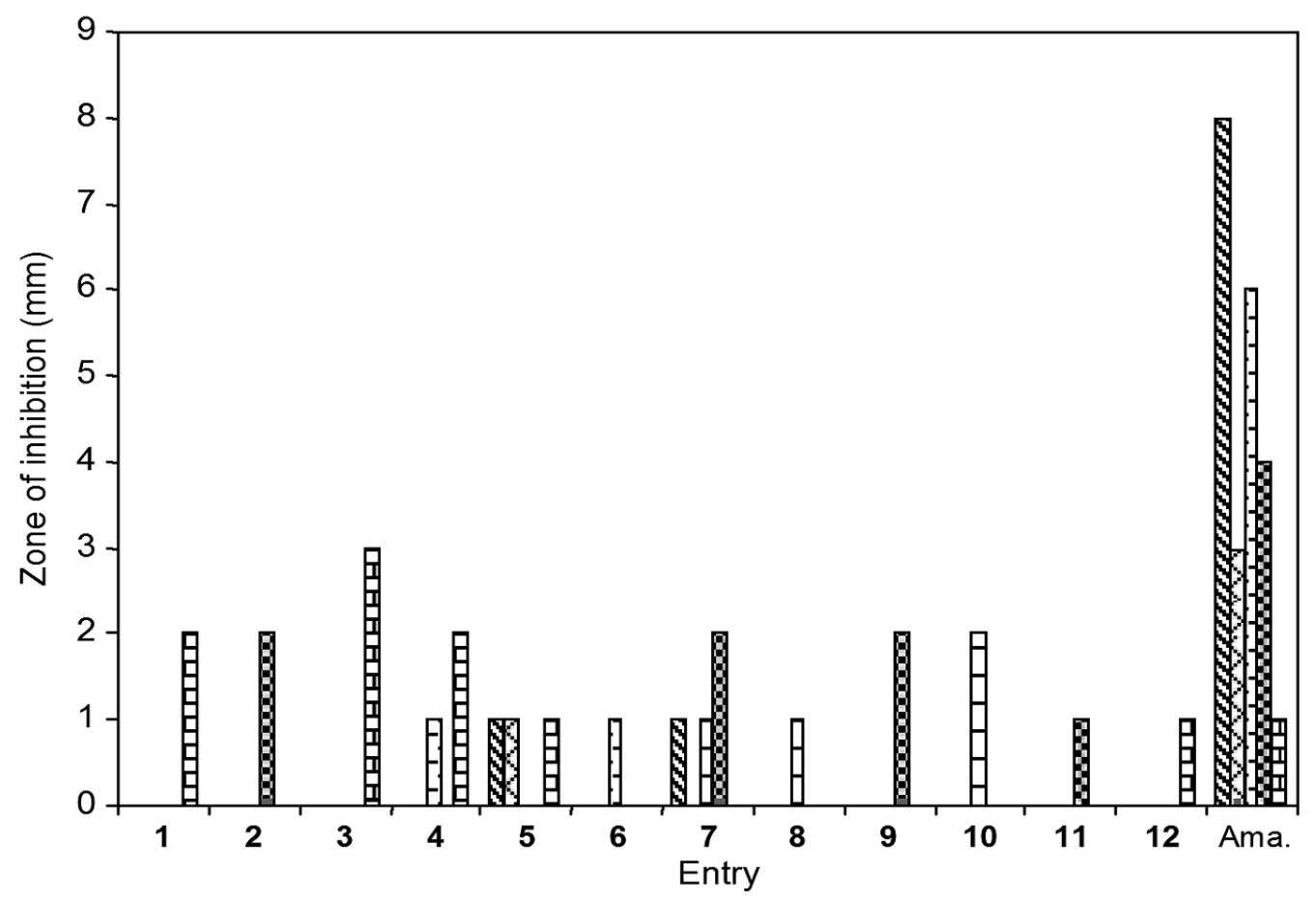

B. subtilis $\mathrm{QM}$. luteus E] S. aureus BE. coli 田P. aeruginosa

Ama. $=$ Amacilin (standard drug)

Fig. 2. Antibacterial activities of (E)-[4-(substituted benzylideneamino)phenyl](phenyl)methanones clustered column chart. 


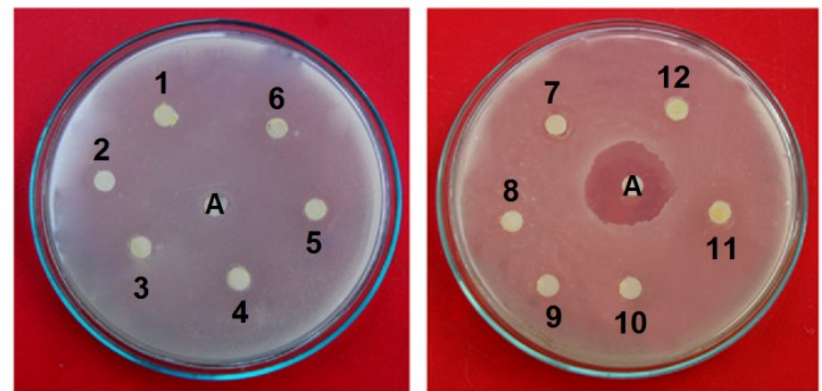

\section{Bacillus subtilis}

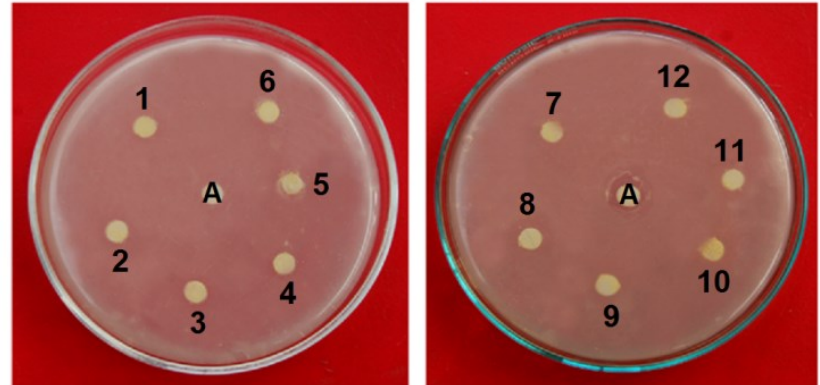

Micrococcus luteus

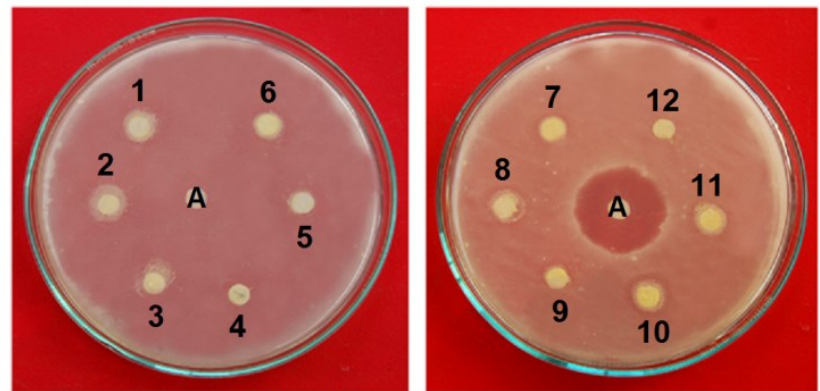

Staphylococcus aureus

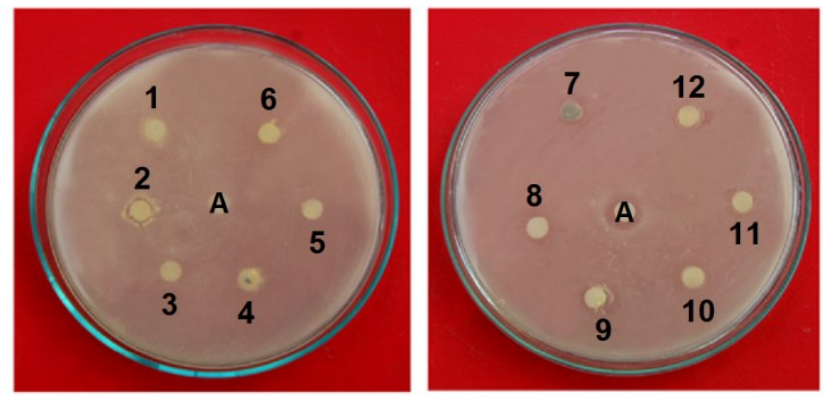

Escherichia coli

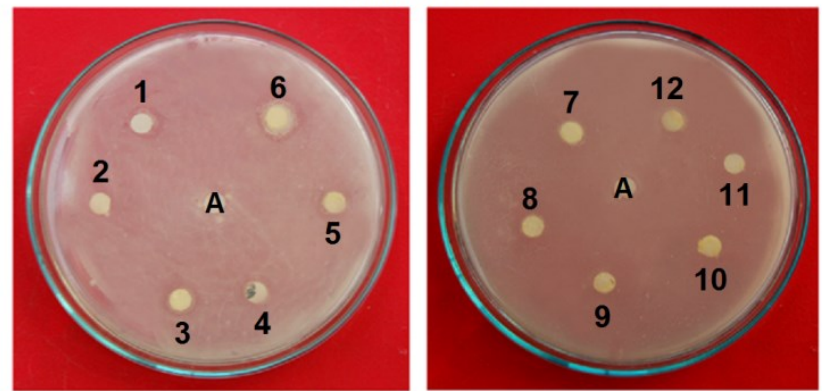

Pseudomonas aeruginosa

Fig. 3. Antibacterial activities of (E)-[4-(substituted benzylideneamino)phenyl](phenyl)methanones. A - Amacilin (standard drug). 


\subsection{Antifungal sensitivity assay}

Antifungal sensitivity assay has been performed using disc diffusion technique [32] PDA medium has prepared and sterilized as above. It has been poured in the petri plate which has been already filled with $1 \mathrm{~mL}$ of the fungal species.

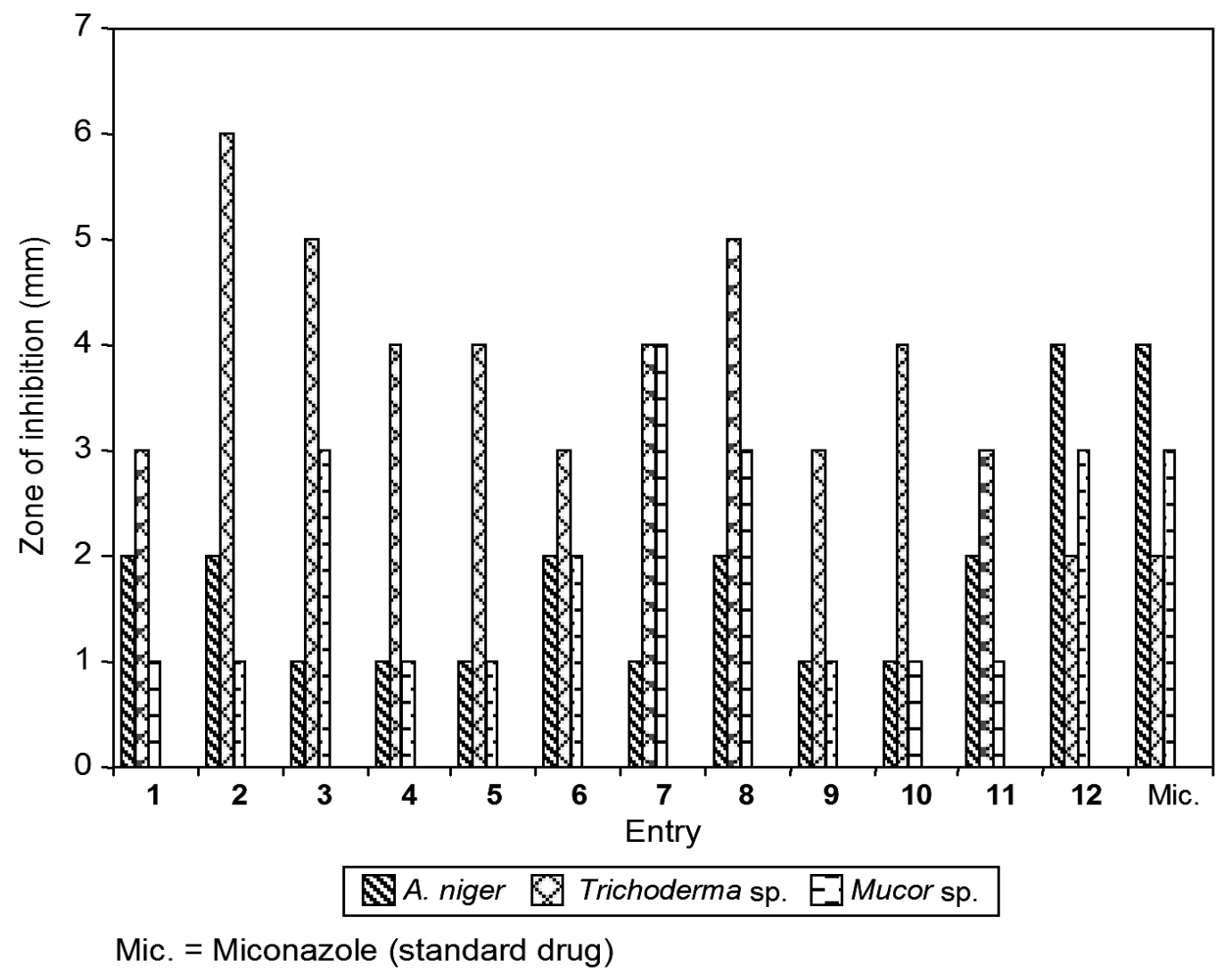

Fig. 4. Antifungal activities of (E)-[4-(substituted benzylideneamino)phenyl](phenyl)methanones clustered column chart.

The plates have been rotated clockwise and counter clockwise for uniform spreading of the species. The discs have been impregnated with the test solution. The test solution has been prepared by dissolving $15 \mathrm{mg}$ of the Schiff's bases in $1 \mathrm{~mL}$ of DMSO solvent. The medium have been allowed to solidify and kept for 3 days.

Then the plates have been visually examined and the diameter values of zone of inhibition have been measured. Triplicate results have been recorded by repeating the same procedure. The antifungal activities of substituted imines have been studied and are shown in Fig. 5 and the zone of inhibition values of the effects is given in Table 4. The clustered column chart is shown in Fig. 4. A good antifungal activity has been possessed by all substituents on the microorganism in general. The substituents $4-\mathrm{NO}_{2}$ have excellent and $\mathrm{H}$, $3-\mathrm{Br}, 4 \mathrm{~N}\left(\mathrm{CH}_{3}\right)_{2}, 3-\mathrm{OCH}_{3}$ and 3- $\mathrm{NO}_{2}$ have moderate activity against Aspergillus niger. The all substituents have been excellent activity against Trichoderma species. The substituent 4-F

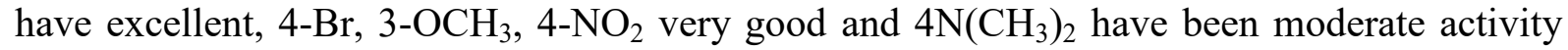
against Mucor species. 


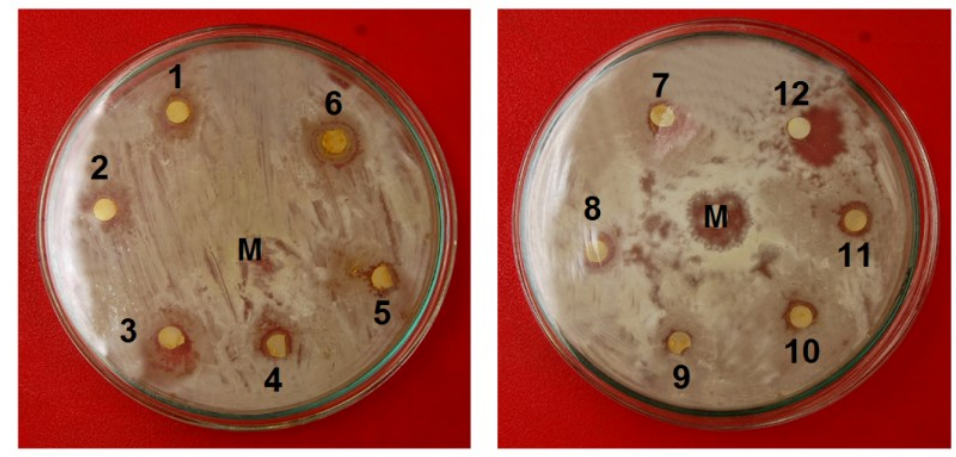

Aspergillus niger

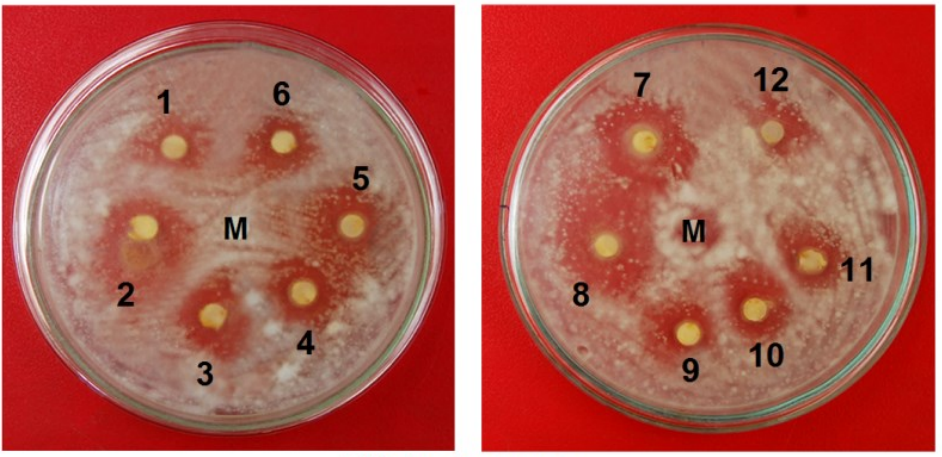

Trichoderma sp.

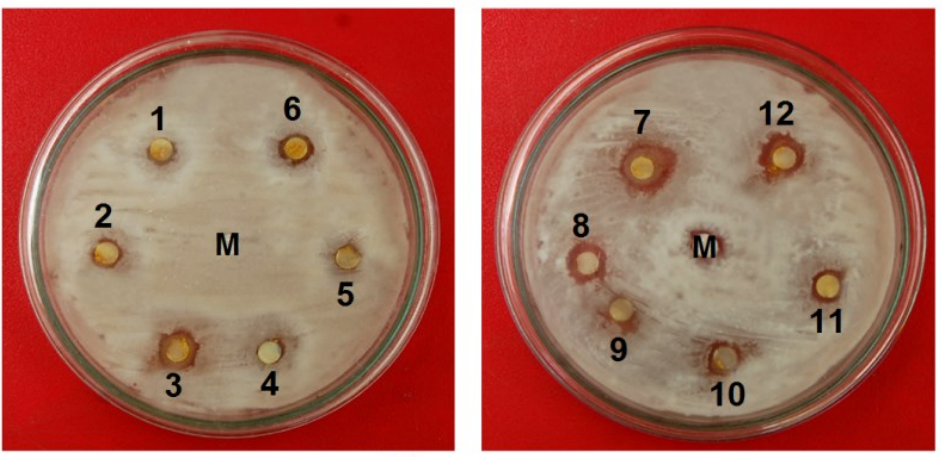

Mucor sp.

Fig. 5. Antifungal activities of (E)-[4-(substituted benzylideneamino)phenyl](phenyl)methanones. $\mathrm{M}$ Miconazole (standard drug). 
Table 4. Antifungal activity of (E)-[4-(substituted benzylideneamino)phenyl](phenyl)methanones.

\begin{tabular}{|c|c|c|c|c|}
\hline \multirow{2}{*}{ Entry } & \multirow{2}{*}{$\mathbf{X}$} & \multicolumn{3}{|c|}{ Zone of inhibition (mm) } \\
\hline & & A. niger & Trichoderma sp. & Mucor sp. \\
\hline 1 & $\mathrm{H}$ & 2 & 3 & 1 \\
\hline 2 & $3-\mathrm{Br}$ & 2 & 6 & 1 \\
\hline 3 & $4-\mathrm{Br}$ & 1 & 5 & 3 \\
\hline 4 & $3-\mathrm{Cl}$ & 1 & 4 & 1 \\
\hline 5 & $4-\mathrm{Cl}$ & 1 & 4 & 1 \\
\hline 6 & $4-\mathrm{N}\left(\mathrm{CH}_{3}\right)_{2}$ & 2 & 3 & 2 \\
\hline 7 & $4-\mathrm{F}$ & 1 & 4 & 4 \\
\hline 8 & $3-\mathrm{OCH}_{3}$ & 2 & 5 & 3 \\
\hline 9 & $4-\mathrm{OCH}_{3}$ & 1 & 3 & 1 \\
\hline 10 & $2-\mathrm{CH}_{3}$ & 1 & 4 & 1 \\
\hline 11 & $3-\mathrm{NO}_{2}$ & 2 & 3 & 1 \\
\hline 12 & $4-\mathrm{NO}_{2}$ & 4 & 2 & 3 \\
\hline \multicolumn{2}{|c|}{ Miconazole } & 4 & 2 & 3 \\
\hline \multicolumn{2}{|c|}{ DMSO } & - & - & - \\
\hline
\end{tabular}

\section{CONCLUSIONS}

A series of Schiff's bases (E)-[4-(substituted benzylideneamino)phenyl](phenyl)methanone have been synthesized by condensation of arylamines and substituted benzaldehyde using microwave irradiation in the presence of fly-ash:PTS under solvents-free conditions. This reaction protocol offers a simple, eco-friendly, non-hazardous easier workup procedure and high yields. These imines were characterized by their physical constants spectral data. The IR, NMR spectral data of these imines have been correlated with Hammett substituent constants, $\mathrm{F}$ and $\mathrm{R}$ parameters. From the results of statistical analyses, the effects of substituents on the spectral data have been studied. The antibacterial activities of all synthesized imines have been studied using Bauer-Kirby method. 


\section{References}

[1] H. Schiff, Justus Liebigs Ann. Chem. 131 (1864) 118-119.

[2] R. Capdeville, E. Buchdunger, J. Zimmermann and A. Matter, Nat. Rev. Drug. Discov. 1 (2002) 493-502.

[3] A. Bongini, M. Panunzio, G. Piersanti, E. Bandini, G. Martelli, G. Spunta and A. Venturini, Eur. J. Org. Chem. 13 (2000) 2379-2390.

[4] V. V. Mulwad and J. M. Shirodkar, Indian J. Heterocyclic Chem. 11 (2002) 199-202.

[5] G. Weber and J. Messerschmidt, Anal. Chim. Acta 545 (2005) 166-172.

[6] T. Fukumura, Kokai Tokkyo Koho (2008) 10pp.

[7] R. Singh and N. K. Kaushik, Main Group Met. Chem. 30 (2007) 333-344.

[8] S. Zhu, Z. Zhou and B. Zhao, Huaxue Yu Shengwu Gongcheng 25 (2008) 34-35.

[9] C. F. Zhu, G. Z. Yuan, E. H. Sheng and Y. Cui, Jiegou Huaxue 28 (2009) 1304-1310.

[10] J. Wang, Y. Song and X. Gao, Hecheng Huaxue 16 (2008) 225-226.

[11] Q. F. Cheng, X. Y. Xu, Q. F. Wang, B. H. Qian, W. J. Liu and X. J. Yang, Jie. Hua. 28 (2009) 1281-1285.

[12] S. France, M. H. Shah, A. Weatherwax, H. Wack, J. P. Roth and T. Lectka, J. Am. Chem. Soc. 127 (2005) 1206-1215.

[13] L. Blackburn and R. J. K. Taylor, Org. Lett. 3 (2001) 637-1639.

[14] M. Gopalakrishnan, P. Sureshkumar, V. Kanagarajan and J. Thanusu, Res. Chem. Intermed. 33 (2007) 541-548.

[15] a) R. J. McBurney, P. C. Fernando and J. C. Walton, Res. Adv. 2 (2012) 1264-1274; b) G. Nagendrappa, Resonance 7 (2002) 59-68.

[16] A. Hasaninejad, A. Zare, H. Sharghi and M. Shekouhy, Arkivoc xi (2008) 64-74.

[17] a) C. M. Bode, A. Ting and S. E. Schaus, Tetrahedron 62 (2006) 11499-11505;

b) P. Lidstrom, J. Tierney, B. Wathey and J. Westman, Tetrahedron 57 (2001) 9225-9283.

[18] M. A. Vazquez, M. Landa, L. Reyes, M. J. Tamariz and D. Francisco, Synth. Commun. 34 (2004) 2705-2718.

[19] R. Suresh, D. Kamalakannan, K. Ranganathan, R. Arulkumaran, R. Sundararajan, S. P. Sakthinathan, S. Vijayakumar, K. Sathiyamoorthi, V. Mala, G. Vanangamudi, K. Thirumurthy, P. Mayavel and G. Thirunarayanan, Spectrochim. Acta A 101 (2013) 239-248.

[20] S. K. Srivastava, S. Srivastava and S. D. Srivastava, Indian J. Chem. 41B (2002) 2357-2363.

[21] R. S. Pattan, V. V. Krishna Reddy, F. V. Manvi and B. G. Desai, Indian J. Chem. 45B (2006) 1778-1781.

[22] a) K. Singh, M. S. Barwa and P. Tyagi, Eur. J. Med. Chem. 41 (2006) 147-153;

b) S.K. Sridhar, M. Saravanana and A. Ramesh, Eur. J. Med. Chem. 36 (2001) 615-625.

[23] K. M. Mistry and K. R. Desai, Indian J. Chem. 45B (2006) 1762-1766. 
[24] a) W. He, M. R. Meyers, B. Hanney, A. Spada, G. Blider, H. Galzeinski, D. Amin, S. Needle, K. Page, Z. Jayyosi and H. Perrone, Bioorg. Med. Chem. Lett. 13 (2003) 3097-3100;

b) K. M. Mistry and K. S. Desai, E-J. Chem. 1 (2004) 189-193.

[25] R. Mino, L. Shuoliong, Y. Rudong and V. L. Y. Welbing, Indian J. Chem. 42 (2003) 318-321.

[26] S. T. Hazeldine, L. Polin, J. Kushner, J. Paluck, K. White, M. Edelstein, E. Palomino, T. H. Corbett and J. P. Horwitz, J. Med. Chem. 44 (2001) 1758-1776.

[27] A. Venturini and R. J. Gonzalez, J. Org. Chem. 67 (2002) 9089-9092.

[28] A. E. Taggi, A. M. Hafez, H. Wack, B. Young, D. Ferraris and T. Lectka, J. Am. Chem. Soc. 124 (2002) 6626-6635.

[29] C. M. L. Delpiccolo and E. G. Mata, Tetrahedron: Asymmetry 13 (2002) 905-910.

[30] K. Sathiyamoorthy, V. Mala, S. P. Sakthinathan, D. Kamalakannan, R. Suresh, G. Vanangamudi and G. Thirunarayanan, Spectrochim. Acta A 112 (2013) 245-256.

[31] G. Thirunarayanan and K. G. Sekar, International Letters of Chemistry, Physics and Astronomy 6 (2014) 39-47.

[32] R. Arulkumaran, R. Sundararajan, V. Manikandan, V. Sathiyendiran, S. Pazhamalai and G. Thirunarayanan, International Letters of Chemistry, Physics and Astronomy 19 (2014) 25-15.

[33] K. G. Sekar and G. Thirunarayanan, International Letters of Chemistry, Physics and Astronomy 8 (2013) 160-174.

[34] G. Thirunarayanan, Int. J. Sci. Res. Know. 1 (2013) 480-596.

[35] G. Thirunarayanan and G. Vanangamudi, Spectrochim Acta A 81 (2011) 390-396.

[36] K. G. Sekar and G. Thirunarayanan, International Letters of Chemistry, Physics and Astronomy 8 (2013) 249-258.

[37] G. Thirunarayanan, International Letters of Chemistry, Physics and Astronomy 9 (2013) 152-161.

[38] G. Thirunarayanan and M. Suresh, International Letters of Chemistry, Physics and Astronomy 4 (2014) 1-11.

[39] G. Thirunarayanan, Bull. Chem. Soc. Ethiop. 28 (2014) 73-79.

[40] G. Thirunarayanan, International Letters of Chemistry, Physics and Astronomy 5 (2014) 89-98.

[41] G. Thirunarayanan and K. G. Sekar, J. Taibah Univ. Sci. 8 (2014) 124-136.

[42] G. Thirunarayanan, K. G. Sekar and R. Lakshmi Narayanan, International Letters of Chemistry, Physics and Astronomy 13 (2014) 88-94.

[43] P. Mayavel, K. Thirumurthy, S. Dineshkumar and G. Thirunarayanan, Q-Science Connect. (2014). doi: http://dx.doi.org/10.5339/connect.2014.10

[44] V. Sathiyendiran, K. G. Sekar, G. Thirunarayanan, R. Arulkumaran, R. Sundararajan, D. Kamalakkannan, R. Suresh, V. Manikanadan, R. Vijayakumar and G. Vanangamudi, International Letters of Chemistry, Physics and Astronomy 11 (2014) 33-43.

[45] G. Thirunarayanan and G. Vanangamudi, Spectrochim. Acta A 81 (2011) 390-396. 
[46] G. Thirunarayanan, M. Gopalakrishnan and G. Vanangamudi, Spectrochim. Acta A 67 (2007) 1106-1112.

[47] G. Thirunarayanan, Int. J. Chem. 1 (2012) 535-541.

[48] G. Thirunarayanan, P. Mayavel, K. Thirumurthy, G. Vanangamudi, K. Lakshmanan and K. Sekar, Int. J. Chem. 1 (2012) 166-172.

[49] G. Thirunarayanan, P. Mayavel, K. Thirumurthy, G. Vanangamudi, K. Lakshmanan and K. Sekar, J. Chil. Chem. Soc. 58 (2013) 2231-2234.

[50] G. Thirunarayanan, Bull. Chem. Soc. Ethiop. 28 (2014) 73-79.

[51] S. P. Sakthinathan, R. Suresh, V. Mala, K. Sathiyamoorthi, D. Kamalakannan, K. Ranganathan, R. Arulkumaran, S. Vijayakumar, R. Sundararajan, G. Vanangamudi and G. Thirunarayanan, International Letters of Chemistry, Physics and Astronomy 6 (2013) 77-90.

[52] S. P. Sakthinathan, R. Suresh, V. Mala, K. Sathiyamoorthi, D. Kamalakannan, K. Ranganathan, S. John Joseph, G. Vanangamudi and G. Thirunarayanan, Int. J. Sci. Res. Know. 1 (2013) 472-483.

[53] B. W. Bauer, W. M. M. Kirby, J. C. Sherris and M. Truck, Am. J. Clin. Pathol. 45 (1996) 493-496.

[54] C. G. Swain and E. C. Lupton Jr, J. Am. Chem. Soc. 90 (1968) 4328-4337. 